\title{
Prepartum Behavior and Dry Matter Intake Identify Dairy Cows at Risk for Metritis
}

\author{
J. M. Huzzey, ${ }^{*}$ D. M. Veira,† D. M. Weary, ${ }^{*}$ and M. A. G. von Keyserlingk ${ }^{* 1}$ \\ ${ }^{*}$ Animal Welfare Program, Faculty of Land and Food Systems, University of British Columbia, 2357 Main Mall, Vancouver, \\ British Columbia, V6T 1Z4, Canada \\ †Agriculture and Agri-Food Canada, PO Box 1000, Agassiz, British Columbia, V0M 1A0, Canada
}

\section{ABSTRACT}

Metritis is a disease of particular concern after calving because of its profound negative effects on the reproductive performance of dairy cows. Cows at risk for metritis have shorter feeding times in the days before calving but prepartum dry matter intake (DMI) and water intake may also be useful in identifying cows at risk for this disease. Feeding, drinking, and intake measures may also be affected by social interactions among group-housed cows. The objective of this study, therefore, was to measure intake, feeding, drinking, and social behavior to determine which measures could identify cows at risk for metritis after calving. Feeding and drinking behavior and intake measures were collected from 101 Holstein dairy cows from 2 wk before until 3 wk after calving using an electronic monitoring system. Social behavior at the feed bunk was assessed from video recordings. Metritis severity was diagnosed based on daily rectal body temperature as well as condition of vaginal discharge that was assessed every $3 \mathrm{~d}$ after calving until $\mathrm{d}+21$. In this study, $12 \%$ of cows were classified as severely metritic and $27 \%$ as mildly metritic. Prepartum feeding time and DMI were best able to identify cows at risk for metritis. Cows that developed severe metritis spent less time feeding and consumed less feed compared with healthy cows beginning 2 wk before the observation of clinical signs of infection. For every 10-min decrease in average daily feeding time during the week before calving, the odds of severe metritis increased by 1.72 , and for every 1-kg decrease in DMI during this period, cows were nearly 3 times more likely to be diagnosed with this disorder. During the week before calving, cows that were later diagnosed with severe metritis had lower DMI and feeding times during the hours following fresh feed delivery. During this period these cows also engaged in fewer aggressive interactions at the

Received December 1, 2006.

Accepted March 16, 2007.

${ }^{1}$ Corresponding author: nina@interchange.ubc.ca feed bins compared with cows that remained healthy. This research is the first to show that social behavior may play an important role in transition cow health. Research is now required to determine how management should be changed to reduce or prevent illness in transition dairy cows.

Key words: transition cow, metritis, intake, behavior

\section{INTRODUCTION}

There is much interest among dairy scientists in finding ways to improve the early identification of disease. Health disorders can have a major impact on the profitability of a dairy herd. As outlined by Gröhn et al. (2003), diseases can influence production efficiency in 3 ways: by reducing milk production, reducing reproductive performance, and by shortening the life expectancy of a dairy cow through increased culling rates. Early identification of sick cows is a critical component of any dairy herd health program.

During the transition period (typically defined as the period from $3 \mathrm{wk}$ before to $3 \mathrm{wk}$ after calving) dairy cows are highly susceptible to metabolic and infectious disease; therefore, early identification of disease may be especially useful at this time. Uterine infection after calving can be costly to producers because uterine infection has been shown to impair reproductive performance (Opsomer et al., 2000; Melendez et al., 2004) and reduce milk yield (Rajala and Gröhn, 1998). Gröhn et al. (2003) suggested that the reproductive status of a cow was the single most important factor influencing culling decisions on farms and that uterine infection likely contributes indirectly to the high rates of involuntary culling.

The terms used to describe uterine infection are often inconsistent across studies. In general, puerperal metritis or metritis (also referred to as primary or early metritis) refers to inflammation of the uterus during the first 21 to $28 \mathrm{~d}$ after calving. The term endometritis generally is reserved to describe uterine infection occurring 21 to $28 \mathrm{~d}$ after calving. This paper 
will focus on early metritis and will refer to this condition as metritis.

The mean incidence of metritis across parity varies among studies $(21.1 \%$, Markusfeld et al., 1997; 2.2\%, Rajala and Gröhn, 1998; 0.7\%, Bruun et al., 2002;69\%, Urton et al., 2005; 21.7\%, Hammon et al., 2006). Diagnostic criteria may be poorly described, which makes it difficult to compare incidence rates. Differences in the methods used to classify uterine infections among studies also contribute to the wide range of incidence rates reported in the literature. The herd veterinarian is responsible for disease detection during routine herd health checks but early warning signs of disease may go unnoticed. Practical methods for improved health monitoring, therefore, would be useful.

Research on feedlot steers has shown that changes in feeding behavior can be used to identify sick animals and to predict morbidity. Sowell et al. (1998, 1999) reported that healthy steers spent longer at the feed bunk and had more feeding bouts than sick animals. A follow-up study by Quimby et al. (2001) showed that electronic monitoring of bunk attendance by animals could be used to detect sick steers $4 \mathrm{~d}$ earlier than trained employees. More recently, work by our research group has shown that reduced time at the feed bunk before calving can be used to identify dairy cows at risk for acute metritis (Urton et al., 2005). Dry matter intake was not measured in any of these previous studies. Changes in intake must be mediated by changes in feeding behavior, but how this occurs is not well understood. Previous work has assumed that those animals that spend more time at the feed bunk will consume greater amounts of feed. Animals may vary considerably in intake rates, however, and this fact could potentially weaken the relationships between feed intake and time spent at the feed bunk. One objective of this study, therefore, was to explore the relationship between feed intake and feeding behavior during the transition period, and to determine if both of these measures could be used to identify cows at risk for metritis after calving.

Water is one of the most important nutrients for a dairy cow (NRC, 2001). Studies have shown that water intake and feed intake are closely linked (Murphy, 1992). Reductions in water intake result in lower feed intake (Burgos et al., 2001). Cows spending less time at the feed bunk may also spend less time at the water trough. The second objective of this study was to determine if water intake or drinking behavior could be used to identify cows at risk for metritis after calving.

Social behavior may also provide an indication of a cow's susceptibility to disease. Greater competition at the feed bunk results in shorter feeding times among cows and more aggressive interactions (Olofsson,
1999; DeVries et al., 2004). Socially subordinate animals are displaced more frequently, particularly at high stocking densities (Huzzey et al., 2006). Stress from aggression may negatively affect the immune system of a dairy cow during the transition period, a time when the cow's innate and acquired defense mechanisms are already suppressed (Mallard et al., 1998). Social competition at the feed bunk during transition may further limit a cow's ability to consume adequate DM. This could be particularly harmful to the transition cow because nutrient requirements are high during late pregnancy and during lactation (Bell, 1995). The final objective of this study was to examine how social behavior at the feed bunk (engaging in or avoiding aggressive interactions at the feed bunk) before calving is related to health status after calving.

\section{MATERIALS AND METHODS}

\section{Animals, Housing, and Diet}

The study was conducted between August 2005 and March 2006 at the University of British Columbia's Dairy Education and Research Center (Agassiz, BC, Canada). Animals were cared for according to the guidelines of the Canadian Council on Animal Care (1993). During this 8-mo period a total of 32 primiparous and 69 multiparous (parity $=3.2 \pm 1.3$; mean \pm SD) Holstein dairy cows were monitored. Parity included the calving event that occurred during the study. Animals were housed in prepartum and postpartum group pens, each containing 20 freestalls fitted with a mattress (Pasture Mat, Promat Inc., Woodstock, Ontario, Canada) covered with $5 \mathrm{~cm}$ of sand bedding, 12 Insentec (Insentec, Marknesse, Holland) feed bins, and 2 Insentec water troughs. Stocking density was maintained at 20 animals per pen. Group composition was dynamic with cows entering and leaving the experiment depending on their expected and actual calving dates. Cows entered the prepartum pen $25 \pm 2 \mathrm{~d}$ before their expected calving date. They were moved to the maternity pen when they showed physical signs of imminent calving (i.e., udder enlargement, milk letdown, relaxation of tail ligament). The maternity pen consisted of a sand-bedded pack with 6 Insentec feed bins and 1 Insentec water trough. A maximum of 2 cows were kept in the maternity pen at any given time and cows were moved to the postpartum pen within $24 \mathrm{~h}$ after calving where they were monitored for an additional $21 \mathrm{~d}$. Cows in the postpartum pen were milked twice daily at approximately 0700 and $1700 \mathrm{~h}$.

Cows were fed twice daily at approximately 0800 and $1600 \mathrm{~h}$. Samples of TMR for both the pre- and postpartum groups were taken on Monday, Wednesday, and Friday. The 3 samples were then pooled to 
create 1 representative weekly sample of the pre- and postpartum TMR. These samples were dried at $60^{\circ} \mathrm{C}$ for $2 \mathrm{~d}$ to determine the DM content. Dried weekly samples were then pooled into monthly samples and sent for nutrient analysis (Cumberland Valley Analytical Services Inc., Maugansville, MD) to determine the average ( $\pm \mathrm{SD}$ ) $\mathrm{CP}, \mathrm{ADF}, \mathrm{NDF}$, total digestible nutrients, and $\mathrm{NE}_{\mathrm{L}}$ content of the feed over the 8-mo study. Cows in the prepartum pen as well as in the maternity pen were fed a close-up TMR consisting of $21.3 \%$ corn silage, $42.8 \%$ alfalfa hay, and $35.9 \%$ concentrate and mineral mix on a DM basis (DM: $50.8 \pm 1.2 \%$, CP: 14.4 $\pm 1.0 \%$ DM, ADF: $35.0 \pm 2.7 \%$ DM, NDF: $45.6 \pm 2.6 \%$ $\mathrm{DM}$, and $\left.\mathrm{NE}_{\mathrm{L}}: 1.4 \pm 0.1 \mathrm{Mcal} / \mathrm{kg}\right)$. Cows in the postpartum pen were fed a TMR consisting of $21.3 \%$ grass silage, $14.7 \%$ corn silage, $12.3 \%$ alfalfa hay, and $51.7 \%$ concentrate and mineral mix on a DM basis (DM: 51.1 $\pm 1.8 \%, \mathrm{CP}: 17.7 \pm 1.0 \% \mathrm{DM}, \mathrm{ADF}: 23.7 \pm 1.4 \% \mathrm{DM}$, $\mathrm{NDF}: 36.1 \pm 1.8 \% \mathrm{DM}$, and $\left.\mathrm{NE}_{\mathrm{L}}: 1.66 \pm 0.02 \mathrm{Mcal} / \mathrm{kg}\right)$.

\section{Feeding Behavior, Drinking Behavior, and Intake}

An electronic feeding system (Insentec) was used to continuously monitor feeding and drinking behavior as well as individual feed and water intakes for all experimental cows. Each cow had a unique passive transponder (High Performance ISO Half Duplex Electronic ID Tag, Allflex, St. Hyacinthe, Quebec, Canada) attached to her ear tag. When a cow approached the bin an antenna detected the cow's transponder and the head gate opened, allowing the cow access to feed or water. At the time the gate opened, the Insentec system recorded the time and the initial weight in the bin. When a cow exited the bin, the head gate closed and the system again recorded the time and the weight in the bin. These data were used to record the duration of each visit to the bin and the amount of feed or water consumed. Dry matter intake measures were obtained by correcting weekly as-fed intakes for the DM content of the feed.

\section{Social Behavior}

Social interactions occurring at the feed bunk were monitored using video cameras (CCTV camera, model WV-BP330; Panasonic, Osaka, Japan) with an F1.4/ $2.5-6 \mathrm{~mm}$ vari-focal lens. Cameras were connected to a video multiplexer (Panasonic Video Multiplexer, WJ FS 416) and a time-lapse videocassette recorder (Panasonic Time-Lapse VCR, AG-6540). Two cameras were spaced evenly and directly above the feed bunk in both the pre- and postpartum pens, and one camera was placed directly above the feed bunk of the maternity pen. Red lights $(100 \mathrm{~W})$ were hung adjacent to the cameras to facilitate video recording at night. Individual cows were identified on the video recordings by unique alphanumeric symbols located on their back and sides. These symbols were placed on the cow using hair dye before cows entered the experiment. During both wk -1 and wk -2 relative to each cow's actual calving date, 2 random days of video were evaluated, providing $4 \mathrm{~d}$ of prepartum video analysis for each cow. For each day of analysis the total number of times a cows was displaced from the feed bunk as well as the total number of times she displaced other individuals was recorded. A displacement from the feed bunk was noted when a cow's head came in contact with a cow who was feeding, such that the feeding cow withdrew its head from the feed bunk. The number of times a cow was displaced from the feed bunk per day was corrected for the amount of time she spent feeding per day, to account for cows being displaced more often simply because they spent more time at the bunk.

\section{Individual Animal Factors}

Body condition score ( 1 to 5 following Wildman et al., 1982) was evaluated on $d-20 \pm 2, d-10 \pm 2$ (relative to expected calving date), and every $3 \mathrm{~d}$ after calving until $d+21$. Body weights were measured at 3 times: $\mathrm{d}-20 \pm 2, \mathrm{~d} 2 \pm 2$, and $\mathrm{d} 22 \pm 2$ relative to calving. The BW were determined by averaging 3 weight measurements taken over 3 consecutive days. Calving difficulty was recorded as either assisted (easy pull or difficult pull) or unassisted. Retained placenta (RP) was diagnosed if, $24 \mathrm{~h}$ after calving, the placenta was observed hanging from the vulva. Cows with RP were treated with penicillin for 3 consecutive days according to standard operating procedures on the farm. After calving daily rectal body temperatures were taken immediately after the morning milking using a digital thermometer (GLA M525/550, GLA Agricultural Electronics, San Luis Obispo, CA). An examination of the udder and milk for clinical signs of mastitis (i.e., hard quarter, heat or swelling, clots in milk, or clear/yellow milk) was performed every $3 \mathrm{~d}$ after calving until $\mathrm{d}+21$.

The time of calving for each individual cow was determined from video recordings and used to express feeding and drinking data such that the day of calving (d 0) started at the time the calf was born. The day before and after the day of calving $(d-1$ and $d+1)$ was also adjusted accordingly, but data from all other days were calculated starting at midnight.

Milk production data was collected during the morning and afternoon milking. These 2 daily milk yields were then summed to provide a total daily milk yield per cow up until $d+21$. 


\section{Metritis Diagnosis}

Vaginal discharge (VD) was evaluated for each cow every $3 \mathrm{~d}$ after calving until $\mathrm{d}+21$. These examinations took place immediately following the morning milking $(0730$ to $0900 \mathrm{~h})$. Manual vaginal examination has been validated and does not cause uterine bacterial contamination, provoke an acute phase protein response, or delay uterine involution (Sheldon, 2002). Before vaginal palpation, the vulva was thoroughly cleaned with a paper towel soaked in an iodine solution (Prepodyne Scrub, Kane Veterinary Supplies, Edmonton, Alberta, Canada) diluted in warm water to remove any feces that could introduce bacteria into the vaginal canal. Discharge was removed by inserting a gloved hand into the vaginal canal up to the cervix; any discharge present in this location was removed for visual evaluation. The appearance and smell of the VD was evaluated and assigned to a category based on the scoring system used by Urton et al. (2005): no mucus or clear mucus $=0$; cloudy mucus or mucus with flecks of pus $=1$; mucopurulent ( $\leq 50 \%$ pus present $)$ and foul smelling $=2$; purulent $(\geq 50 \%$ pus present $)$ and foul smelling $=3$; and putrid (red/brown color, watery, foul smelling) $=4$.

\section{Determination of Health Status and Cow Participation in Study}

Sixteen cows exhibiting clinical signs of mastitis (i.e., clots/abnormal milk) were removed from the study and 7 cows were removed from the study because of miscellaneous health problems requiring veterinary treatment (e.g., tail infection, severe vaginal tear, torn teat, bowel obstructions). Cows were classified as having severe metritis if they had at least one VD score of 4 and one recording of fever $\left(\geq 39.5^{\circ} \mathrm{C}\right)$. Five cows exhibited at least one VD score of 4 but did not exhibit a fever and consequently were removed from the study. Cows were classified as having mild metritis if they had at least one VD score of 2 or 3 and no VD score of 4. Mildly metritic cows may or may not have had a fever. These definitions are similar to the clinical definitions of puerperal and clinical metritis defined by Sheldon et al. (2006). Healthy cows were identified if they had a maximum VD score of 1 and no fever after calving. There were 11 cows identified with a maximum VD score of 1 as well as a fever and these cows were removed from the study. Following removal of cows that failed to meet the criteria for our 3 health categories, 62 cows (of the original 101) participated in the study: 12 severely metritic (5 primiparous and 7 multiparous), 27 mildly metritic ( 12 primiparous and 15 multiparous), and 23 healthy (5 primiparous and 18 multiparous). The incidence of metritis is strongly related to the presence of $\mathrm{RP}$ (Curtis et al., 1985; Kaneene and Miller, 1995; Bruun et al., 2002). In our study 7 severely metritic cows had an RP, whereas 2 mildly metritic cows had a RP. These animals were not removed from the study because this would have resulted in an insufficient sample size of severely metritic cows $(n=5)$ to carry out meaningful statistical analyses between groups. Although 2 cows in the severely metritic group gave birth to twins, removal of these animals from the severely metritic group did not change the results of our statistical analyses. These cows, therefore, were not removed from the study.

\section{Statistical Analyses}

Statistical analyses were performed with SAS (version 9.1; SAS Institute, 2003) using cow $(\mathrm{n}=62)$ as the experimental unit. Differences between actual and predicted calving dates resulted in differences in length of stay in the prepartum pen $(24 \pm 5 \mathrm{~d}$, mean \pm SD) but complete data were available from $d-13$ relative to the actual calving date. Feeding and drinking events were screened for normality and the presence of outliers by visual assessment of the distributions using PROC UNIVARIATE (SAS Institute, 2003). Of 155,779 feeding events, $4.9 \%$ were identified as extreme outliers (observations that lay more than 3 times the interquartile range from the first or third quartile of the data set), likely due to the system not recording when the cow left the bin. Of 31,775 drinking observations, $1.6 \%$ were identified as outliers. Five experimental periods were defined for analysis: wk -2 ( $d-13$ to $d-8)$, wk -1 ( $d-7$ to $d-1)$, wk $+1(d+1$ to $d$ $+7), w k+2(d+8$ to $d+14)$, and $w k+3(d+15$ to $d+21)$. Because of the well-known differences in behavior/intake and differences in risk of disease across these periods, we tested the effects separately by period. Data for the day of calving (d 0) was not included in an experimental period. The day of calving, however, was used for the descriptive analysis of behavior around calving. Differences in feeding, drinking, DMI, and water intake between healthy cows vs. severely metritic cows and healthy cows vs. mildly metritic cows were analyzed by period using the contrast statement in a mixed model (SAS Institute, 2003) where health status (healthy, severely metritic, or mildly metritic) and parity (primiparous or multiparous) were treated as fixed effects. The DMI was also considered as a percentage of BW; however, these results did not differ from the results obtained using the unadjusted values. The unadjusted DMI, therefore, are reported below. Before this analysis, period means of primiparous and multiparous cows in each health category were assessed separately to determine if any obvious 
health status by parity interactions were present. This preliminary analysis did not reveal any obvious interactions. The interaction, therefore, was not included in the mixed models discussed above because of insufficient sample size of primiparous and multiparous cows in each health category.

The above analyses showed that the strongest differences among health groups in prepartum feeding and drinking behavior occurred during the week before calving (wk-1). The following analyses focused on this period. Differences among health categories in the distribution of feeding and drinking activity over a 24-h period were determined using a mixed model (SAS Institute, 2003) using a heterogeneous autoregressive covariance structure (feed analysis) and a heterogeneous compound symmetry covariance structure (water analysis). A Type I analysis was used for fixed effects in the following order: parity, hour, health status, and health status by hour. Cow was treated as a random effect and hour as a repeated measure.

Multivariate logistic regression was performed using the LOGISTIC procedure (SAS Institute, 2003) to model the effects of various intake and behavioral measures during wk -1 as well as BCS, BW, number of days on the close-up diet (i.e., time spent in the prepartum pen), gestation length, dystocia (assisted or unassisted calving), and parity on the presence or absence of severe metritis. Logistic models were used to fit one covariate at a time; variables with $P<0.2$ were then used to construct a complete logistic model. Variables included in this model were dystocia, days on close-up diet, gestation length, and wk -1 DMI, feeding time, and water intake. Feeding time and DMI were analyzed in separate logistic models due to the significant relationship between these 2 variables $\left(\mathrm{R}^{2}=0.60, P<0.001\right)$. Water intake was positively correlated with DMI $\left(\mathrm{R}^{2}=0.27, P=0.001\right)$ and tended to be correlated with feeding time $\left(\mathrm{R}^{2}=0.10, P=0.06\right)$ during wk -1 and therefore was also analyzed in a separate logistic model. Number of days on the closeup diet was highly correlated with gestation length $\left(\mathrm{R}^{2}=0.98, P<0.001\right)$; when gestation length was substituted for days on the close-up diet in each of the logistic models, the odds ratios for DMI, feeding time, and water intake remained nearly identical. Therefore, the odds ratios for these 3 variables reported in this paper will be from the logistic model that includes dystocia and days on the close-up diet. Variables were included into the model using a forward stepwise procedure based on a selection criterion of $P<0.05$. A Type I analysis of the main effects based on estimated coefficients and their SE and the likelihood ratio and Wald tests resulted in the following order of entry: dystocia, days on close-up diet, wk -1 DMI (or wk -1 feeding time, or wk -1 water intake).

Differences in social behavior during the prepartum period between healthy and mildly metritic cows and healthy and severely metritic cows were tested using $t$-tests. This test was based on a subsample of 36 cows: the 12 severely metritic cows and 12 cows from both the healthy and mildly metritic group. These 3 groups were first balanced for day of calving. Because group composition was dynamic, care was taken to ensure that the healthy and mildly metritic cows selected for the social analysis were interacting with the same individuals that the severely metritic cows had to interact with while in the study. Second, groups were balanced for parity $(2.7 \pm 0.5,2.0 \pm 0.3$, and $2.9 \pm 0.6$, for the healthy, mildly metritic, and severely metritic groups, respectively).

Differences in milk production during the $3 \mathrm{wk}$ following calving among healthy, mildly metritic, and severely metritic cows were tested using a mixed model (SAS Institute, 2003) with a compound symmetry covariance structure and a Type I analysis fixed effects in the following order: parity, day, health status, and health status by day. Cow was treated as a random effect and day as a repeated measure.

\section{RESULTS}

The average number of days from calving to the first signs of pathological discharge (VD score $\geq 2$ ) was 5.3 $\pm 0.5 \mathrm{~d}$ for cows with severe metritis and $9.1 \pm 0.7 \mathrm{~d}$ for cows with mild metritis $(P<0.001)$. The average prepartum BCS of healthy, mildly metritic, and severely metritic cows was $3.4 \pm 0.04,3.3 \pm 0.05$, and $3.4 \pm 0.04$, respectively. Mildly metritic and severely metritic cows produced on average $5.7 \pm 0.4$ and $8.3 \pm$ $0.5 \mathrm{~kg}$ less milk per day $(P<0.001)$ during the first 3 wk of lactation relative to healthy cows, respectively. The analysis of milk production also indicated an interaction between health status and day relative to calving $(P=0.02)$ whereby the differences in milk production between the 3 health categories became greater as the days relative to calving increased (Figure 1).

\section{DMI and Feeding Behavior}

Severely metritic cows consumed less feed than healthy cows beginning $2 \mathrm{wk}$ before calving and continued to consume less DM throughout the 4 remaining week of the study (Table 1). Cows with mild metritis ate less DM compared with healthy animals during the week before calving and throughout the 3-wk postpartum period (Table 1). Cow parity only affected DMI 


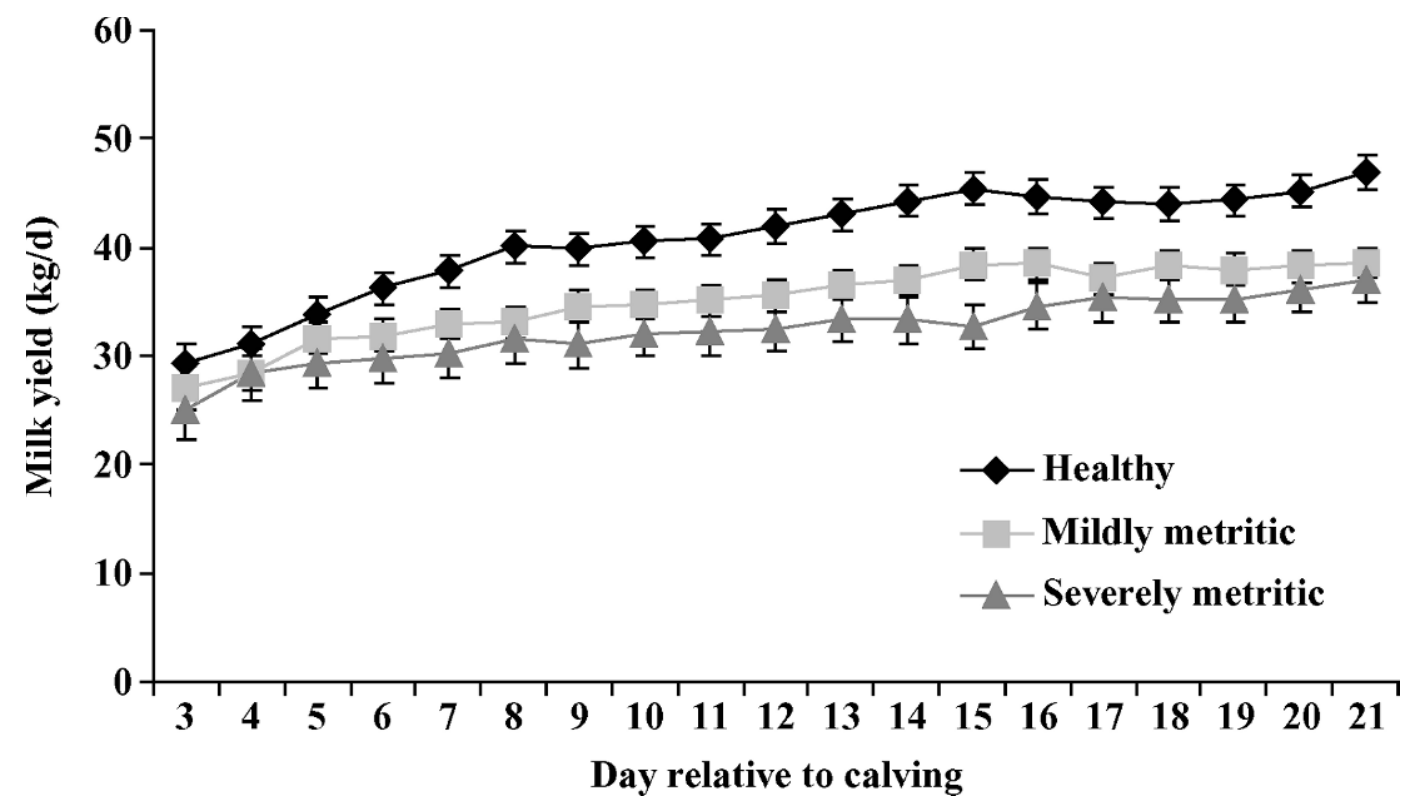

Figure 1. Least squares mean $( \pm \mathrm{SE})$ milk yield $(\mathrm{kg} / \mathrm{d})$ during the first 3 wk of lactation for healthy $(\mathrm{n}=23)$, mildly metritic $(\mathrm{n}=27)$, and severely metritic $(\mathrm{n}=12)$ Holstein dairy cows.

during wk -2 when primiparous cows consumed less feed than multiparous cows $(P=0.04)$, and during wk +2 when primiparous cows consumed more feed $(P=$ $0.05)$; there was no effect of parity at any other experimental period.

Between $d-7$ and $d-2$, healthy, mildly metritic, and severely metritic cows decreased their average daily DMI at a rate of $0.15,0.21$, and $0.33 \mathrm{~kg} / \mathrm{d}$, respectively (Figure 2A). Not surprisingly, there was a drop in the DMI on $d-1$ (relative to the previous day) for the healthy, mildly metritic, and severely metritic cows
( 33,35 , and $31 \%$, respectively), followed by an increase in DMI $(28,49$, and $40 \%$, respectively) in the $24 \mathrm{~h}$ after calving. Of particular interest was that all 3 groups again decreased their DMI by 11,13 , and $34 \%$, respectively on $d+1$.

Cows with severe metritis spent less time feeding than healthy cows during each of the 5 periods, with differences most pronounced during the week before and the week after calving (Table 1). Cows with mild metritis tended to have lower feeding times in the week before calving relative to healthy cows, and had

Table 1. Least squares mean $( \pm \mathrm{SE})$ for DMI, feeding time, and water intake for healthy Holstein dairy cows $(\mathrm{n}=23)$ and those with severe $(\mathrm{n}=12)$ and mild $(\mathrm{n}=27)$ metritis during 5 experimental periods (wk $-2,-1,+1,+2$ and +3$)^{1}$

\begin{tabular}{lccccc}
\hline & \multicolumn{5}{c}{ Period } \\
\cline { 2 - 6 } Item & wk -2 & wk -1 & wk +1 & wk +2 & wk +3 \\
\hline DMI (kg/d) & & & & \\
$\quad$ Healthy & $14.9 \pm 0.5$ & $14.3 \pm 0.5$ & $14.8 \pm 0.7$ & $16.5 \pm 0.7$ & $17.4 \pm 0.7$ \\
$\quad$ Mild metritis & $14.3 \pm 0.4$ & $12.7 \pm 0.5^{*}$ & $12.2 \pm 0.6^{* *}$ & $13.9 \pm 0.6^{* *}$ & $15.5 \pm 0.6^{*}$ \\
$\quad$ Severe metritis & $13.1 \pm 0.6^{*}$ & $11.2 \pm 0.7^{* * *}$ & $8.8 \pm 0.9^{* * *}$ & $12.1 \pm 0.9^{* * *}$ & $13.6 \pm 0.9^{* *}$ \\
Feeding time (min/d) & & & & \\
$\quad$ Healthy & $214.1 \pm 8.4$ & $192.3 \pm 8.9$ & $155.5 \pm 7.4$ & $179.2 \pm 9.2$ & $188.8 \pm 9.9$ \\
Mild metritis & $203.8 \pm 7.2$ & $170.7 \pm 7.7^{\dagger}$ & $130.8 \pm 6.4^{*}$ & $158.4 \pm 8.0 \dagger$ & $176.2 \pm 8.6$ \\
$\quad$ Severe metritis & $184.8 \pm 10.9^{*}$ & $146.0 \pm 11.6^{* *}$ & $91.6 \pm 9.7^{* * *}$ & $147.1 \pm 12.0^{*}$ & $160.5 \pm 12.9 \dagger$ \\
Water intake (kg/d) & & & & \\
$\quad$ Healthy & $39.7 \pm 1.6$ & $37.8 \pm 1.6$ & $63.7 \pm 2.9$ & $77.9 \pm 2.6$ & $82.4 \pm 2.4$ \\
Mild metritis & $34.5 \pm 1.4^{*}$ & $32.8 \pm 1.4^{*}$ & $54.7 \pm 2.5^{*}$ & $62.4 \pm 2.2^{* * *}$ & $71.1 \pm 2.1^{* * *}$ \\
Severe metritis & $36.5 \pm 2.1$ & $32.9 \pm 2.1^{*} \dagger$ & $52.3 \pm 3.8^{*}$ & $68.5 \pm 3.4^{*}$ & $69.0 \pm 3.1^{* *}$ \\
\hline
\end{tabular}

${ }^{1}$ Significance level for difference between mildly metritic and healthy cows and severely metritic and healthy cows: $\dagger P<0.10$; $* P<0.05$; $* * P<0.01$; *** $P<0.001$. 

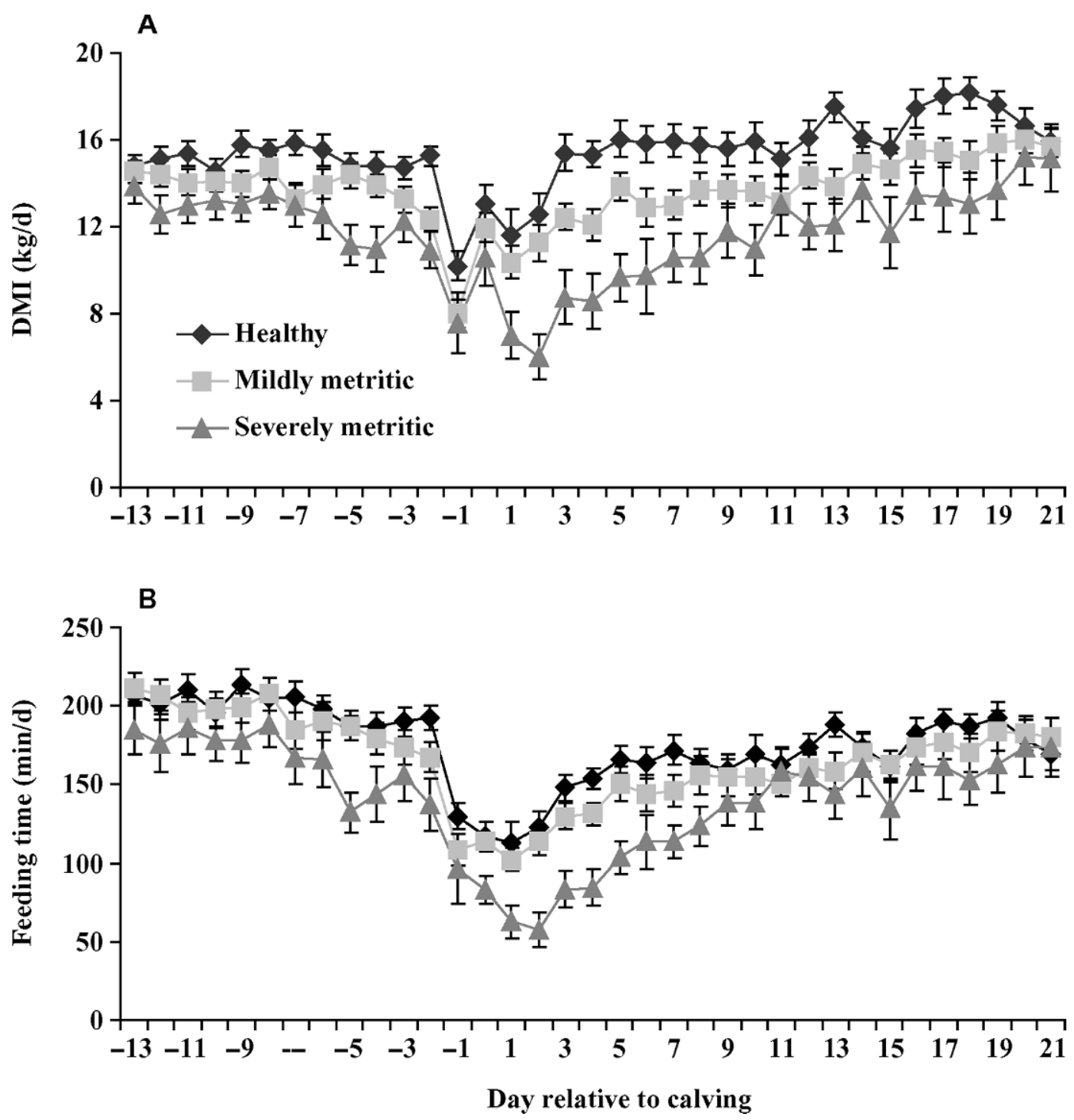

Figure 2. Arithmetic mean $( \pm \mathrm{SE})$ daily DMI $(\mathrm{kg} / \mathrm{d} ; \mathrm{A})$ and feeding time $(\mathrm{min} / \mathrm{d} ; \mathrm{B})$ of healthy $(\mathrm{n}=23)$, mildly metritic $(\mathrm{n}=27)$, and severely metritic $(\mathrm{n}=12)$ Holstein dairy cows from $13 \mathrm{~d}$ before until $21 \mathrm{~d}$ after calving.

lower feeding times during wk +1 . There was also a tendency for cows diagnosed with mild metritis to spend less time eating during $w \mathrm{k}+2$. Irrespective of health status, primiparous cows had longer feeding times than multiparous cows $(P \leq 0.01)$. Similar to the results for DMI, cows progressively decreased their feeding times between $d-7$ and $d-2$ at a rate of 2.6 , 4.0 , and $4.8 \mathrm{~min} / \mathrm{d}$ for healthy, mildly metritic, and severely metritic cows, respectively (Figure 2B). On the day before calving, feeding times dropped dramatically for healthy, mildly metritic, and severely metritic cows $(33,35$, and $30 \%$ decrease, respectively) relative to $\mathrm{d}-2$. However, in contrast to the results obtained from DMI there was no increase in time spent feeding on the day of calving. Although healthy and mildly metritic cows showed relatively stable feeding times during the days around calving followed by a steady increase in daily feeding time after $d+1$, cows diagnosed with severe metritis further reduced their daily feeding times between $d-1$ and $d+2$ at a rate of 13.6 $\mathrm{min} / \mathrm{d}$ (Figure 2B). Feeding time was positively related to DMI, especially for cows with severe metritis (prepartum period; i.e., $\mathrm{d}-13$ to $\mathrm{d}-1, \mathrm{R}^{2}=0.36,0.41$, and 0.64 for healthy, mildly metritic, and severely metritic cows, respectively, $P<0.001$; postpartum period; i.e., $\mathrm{d}-1$ to $\mathrm{d}+21, \mathrm{R}^{2}=0.67,0.69$, and 0.81 , respectively, $P<0.001)$.

There were no differences in feeding rate relative to that of healthy cows during any of the 5 experimental periods for either category of metritic cows (data not 
A

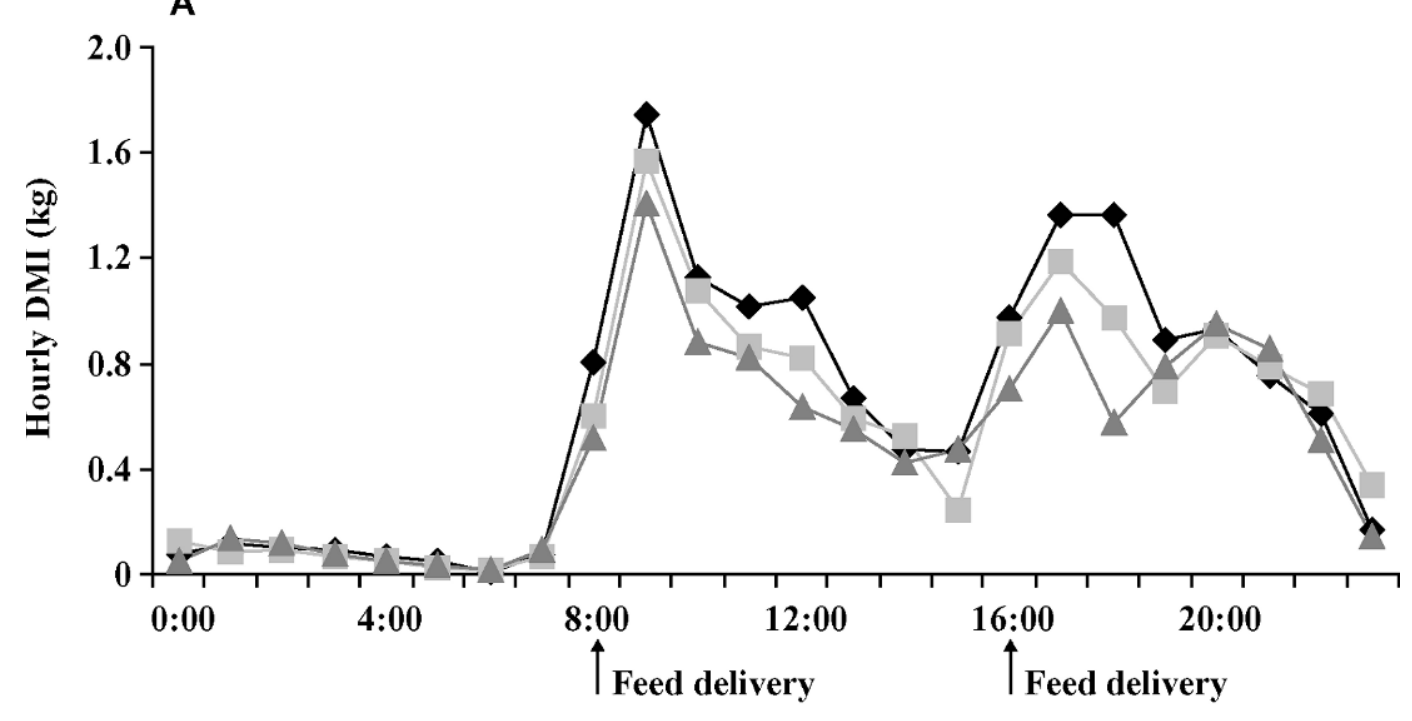

B

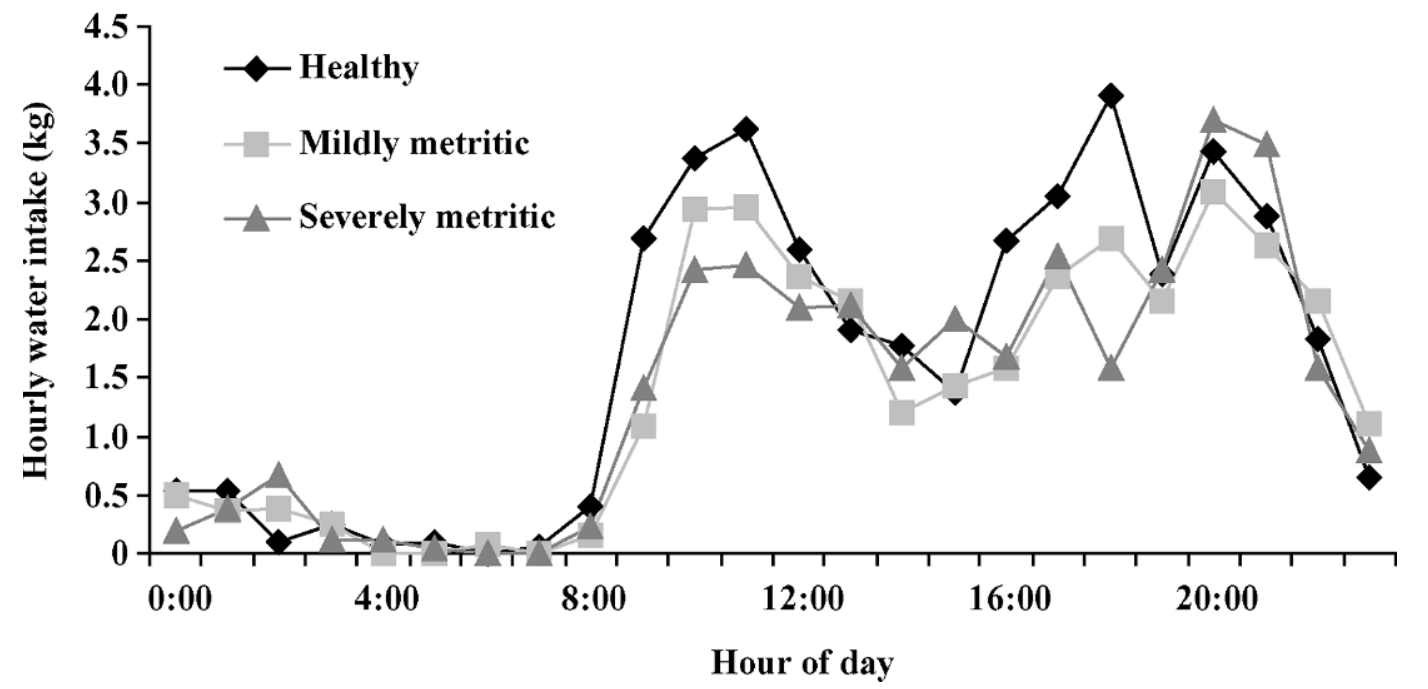

Figure 3. Diurnal pattern of hourly feed consumption (least squares means \pm SE: DMI; A) and water intake (least squares means \pm SE: water; B) for healthy $(n=23)$, mildly metritic $(n=27)$, and severely metritic $(n=12)$ Holstein dairy cows during the week before calving $(\mathrm{d}-7$ to $\mathrm{d}-2)$.

shown). Although feeding rate remained relatively stable during the 2 wk before calving, there were 46,37 , and $50 \%$ increases in feeding rate for healthy, mildly metritic, and severely metritic cows, respectively, on the day of calving. Primiparous cows ate slower than multiparous cows $(P \leq 0.02)$ throughout the study.

Analysis of the diurnal pattern of DMI and feeding time during the week before calving showed differences in hourly DMI and feeding time between healthy, and mildly or severely metritic dairy cows ( $P$ $\leq 0.003$; Figure 3A). We observed a health status by hour interaction for DMI $(P=0.03)$ indicating that differences in hourly intake were affected by time of day. The strongest differences in DMI between health categories occurred in the hours immediately following fresh feed delivery in the morning and afternoon. We noted a tendency for a similar health status by hour interaction $(P=0.06)$ for feeding time. There were no differences in hourly feeding rate between the 3 health categories during the week before calving $(P=0.73)$.

\section{Drinking Behavior and Water Intake}

Cows with severe or mild metritis consumed less water than healthy cows during the 3 wk after calving. Moreover, although severely metritic cows showed a 


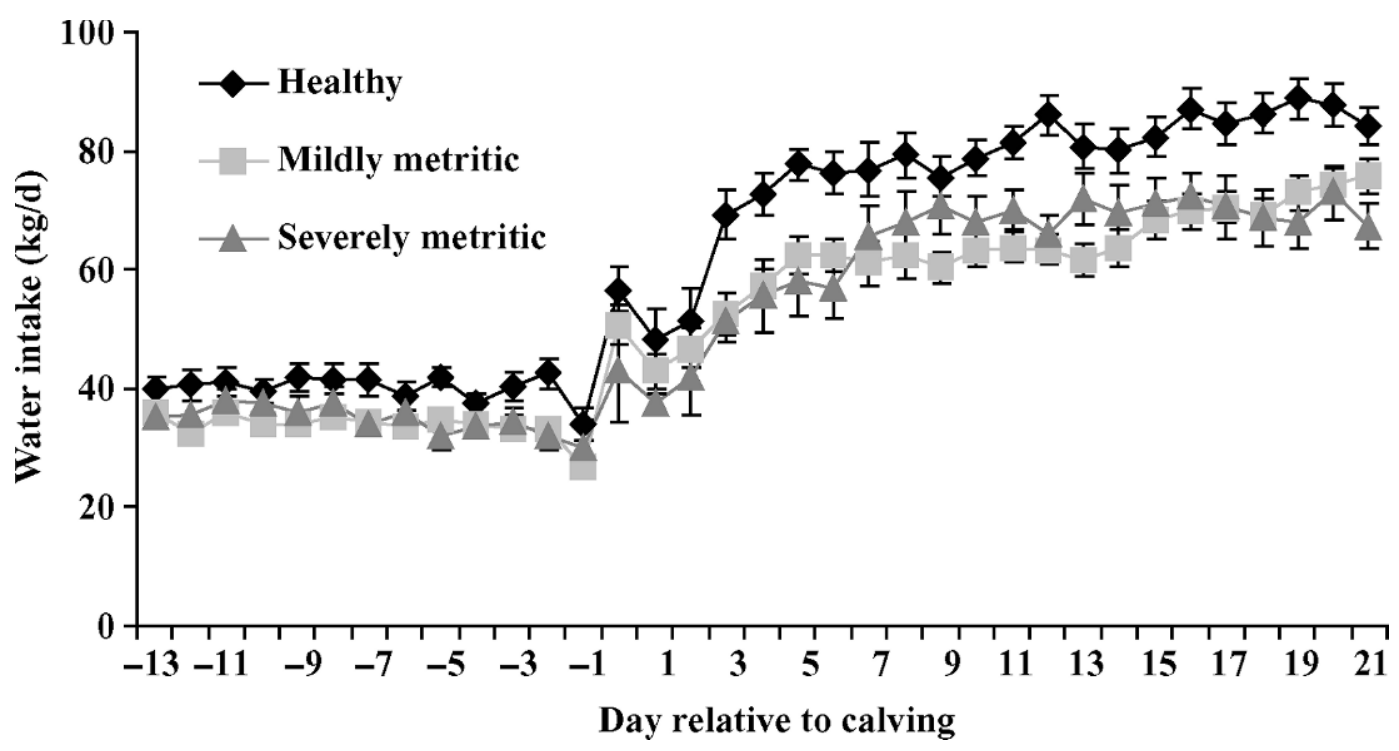

Figure 4. Arithmetic mean $( \pm \mathrm{SE})$ daily water intake $(\mathrm{kg} / \mathrm{d})$ of healthy $(\mathrm{n}=23)$, mildly metritic $(\mathrm{n}=27)$, and severely metritic $(\mathrm{n}=12)$ Holstein dairy cows from $13 \mathrm{~d}$ before until $21 \mathrm{~d}$ after calving.

tendency to consume less water during the week before calving, mildly metritic cows consumed less water then healthy cows during the $2 \mathrm{wk}$ preceding calving (Table 1). For healthy, mildly metritic, and severely metritic cows, respectively, there was a 20,19 , and $7 \%$ decline in water intake on $d-1$, followed by a 67,89 , and $44 \%$ respective increase in water intake on the day of calving (Figure 4). Water intake dropped by $15 \%$ for healthy and mildly metritic cows and by $13 \%$ for severely metritic cows on $d+1$. Unlike the pattern observed for DMI there was no obvious decline in water intake in the week before calving (Figure 4). Primiparous cows consumed less water than multiparous cows $(P \leq 0.04)$ throughout the study.

There were no differences between healthy cows and those diagnosed with either severe or mild metritis in total time spent drinking per day (data not shown), and no effect of parity on time spent drinking. There were weakly positive relationships between drinking time and total amount of water consumed for healthy, mildly metritic, and severely metritic cows during the prepartum $\left(\mathrm{d}-13\right.$ to $\mathrm{d}-1 ; \mathrm{R}^{2}=0.23,0.03$, and 0.07 , respectively, $P<0.001)$ and postpartum periods $(\mathrm{d}+1$ to $\mathrm{d}+21 ; \mathrm{R}^{2}=0.10,0.08$, and 0.26 , respectively, $P$ $<0.001$ ).

There were no differences in the drinking rate between healthy cows and those later diagnosed with severe metritis (data not shown). However, mildly metritic cows had slower rates of water consumption than healthy cows; during the week before calving the drinking rate of mildly metritic cows was approxi- mately $1.6 \mathrm{~kg} / \mathrm{min}$ slower then healthy cows $(P=0.05)$, and during the $3 \mathrm{wk}$ after calving, their drinking rate was on average $2.0 \mathrm{~kg} / \mathrm{min}$ slower $(P=0.01)$. Primiparous cows drank more slowly than multiparous cows $(P \leq 0.05)$.

The diurnal pattern of water intake (Figure 3B) and drinking rate during the week before calving was different among the 3 health categories $(P \leq 0.007)$. Analysis of drinking rate indicated an interaction between health status and hour $(P<0.001)$. Differences in drinking rate were most pronounced following the delivery of fresh feed with healthy cows drinking faster during these periods. There were no differences in hourly drinking time among the 3 health categories during the week before calving $(P=0.37)$.

\section{Logistic Regression}

Logistic regression showed that dystocia, days on close-up diet (or gestation length), wk -1 DMI, and wk -1 feeding time were associated with an increased risk of developing severe metritis. Water intake during wk -1 tended to be associated with an increased risk for severe metritis. The odds of cows being diagnosed with severe metritis increased by 15.8 when calving was assisted relative to when it was not $\left[P_{\text {Wald }}=0.004\right.$; 95\% confidence interval $\left.\left(\mathbf{C I}_{\mathbf{9 5}}\right)=2.36,105.49\right]$ and increased by 1.19 for every day less that a cow consumed the close-up diet before calving $\left(P_{\text {Wald }}=0.04 ; \mathrm{CI}_{95}=\right.$ $1.01,1.41)$. When gestation length was substituted into the logistic model the odds of metritis increased 
by 1.22 for every day less in gestation length $\left(P_{\text {Wald }}=\right.$ $\left.0.03 ; \mathrm{CI}_{95}=1.02,1.47\right)$. The odds of severe metritis increased by 2.87 for every 1-kg decrease in DMI during the week before calving $\left(P_{\text {Wald }}=0.02 ; \mathrm{CI}_{95}=1.16\right.$, 7.09). This logistic model (including dystocia, days on close-up diet, and DMI during wk -1) accounted for $58 \%$ of the variation in risk of severe metritis $\left[R^{2}=\right.$ $\left.0.58, P_{\text {Likelihood Ratio }}<0.001\right]$. The odds of severe metritis increased by 1.72 for every 10-min decrease in feeding time during wk $-1\left(P_{\text {Wald }}=0.02 ; \mathrm{CI}_{95}=1.08,2.75\right)$. In this logistic model that substituted feeding time for DMI, $54 \%$ of the variation in risk of severe metritis was accounted for $\left(\mathrm{R}^{2}=0.54, P_{\text {Likelihood Ratio }}<0.001\right)$. The logistic model including water intake accounted for $44 \%$ of the variation in risk of severe metritis, with the odds of severe metritis increasing by 1.21 for every $1-\mathrm{kg}$ decrease in water intake during wk $-1\left(P_{\text {Wald }}=\right.$ $0.09 ; \mathrm{CI}_{95}=0.97,1.52$ ).

\section{Social Behavior}

During the 2 wk before calving healthy cows displaced others from the feed bins on average $16.8 \pm 1.74$ times/d compared with severely metritic cows who only displaced others on average $12.2 \pm 1.58$ times $/ \mathrm{d}(P=$ $0.06)$. There was no difference between healthy and mildly metritic cows in terms of how often they displaced others at the feed bunk during the prepartum period. After adjusting for the time each cow spent feeding per day there were no differences between the health categories in terms of the number of times individuals were displaced from the feed bunk. Multiparous cows were more aggressive at the feed bunk, displacing others on average $17.9 \pm 1.2$ times/d relative to primiparous cows that displaced others on average $11.5 \pm 1.5$ times $/ \mathrm{d}(P=0.002)$. Primiparous cows were displaced from the feeding area more often than they displaced others, whereas multiparous cows displaced others more often then they were displaced by other cows $(P<0.001)$.

\section{DISCUSSION}

Milk production was lower in those cows identified with severe and mild metritis in our study during the first 3 wk after calving. This reduction in milk production is likely a consequence of the lower DMI and water intake observed after calving in the severely and mildly metritic cows. Other studies have also reported that cows diagnosed with metritis within the first few weeks after calving showed lower milk yields particularly during early lactation (Deluyker et al., 1991; Rajala and Gröhn, 1998).

A variety of risk factors have been associated with metritis, with the most frequently cited factors being
$\mathrm{RP}$ and calving difficulty (Curtis et al., 1985; Kaneene and Miller, 1995; Bruun et al., 2002). Similarly, we noted that $58 \%$ of severely metritic cows had RP, whereas only $7 \%$ of the mildly metritic cows and none of the healthy cows were diagnosed with RP. Neutrophil functioning is depressed during the weeks around calving (Detilleux et al., 1995), and Kimura et al. (2002) suggested that reduced neutrophil functioning was a determining factor for development of RP in dairy cattle. In addition we showed that cows were 15.8 times more likely to develop severe metritis if they had an assisted calving. Calving difficulty increases trauma to the uterine wall and may increase susceptibility to disease by increasing the risk of harmful bacteria entering the reproductive tract (Bruun et al., 2002). Uterine trauma, which can result from dystocia or manual removal of $\mathrm{RP}$, has also been linked with reduced immune functioning (i.e., reduced phagocytic activity of uterine and blood neutrophils; Paisley et al., 1986).

Days spent consuming the close-up diet was highly correlated with gestation length because both variables were influenced by predicted and actual calving dates. For both of these variables, fewer days on the close-up diet or in gestation length was associated with an increased risk of severe metritis. Due to the high correlation between these variables it is unclear whether one factor is more important then the other as a risk factor for metritis. Markusfeld (1984) reported that heifers with long gestation lengths ( $>281$ d) were at greater risk of early metritis, whereas cows with shorter gestation lengths $(<270 \mathrm{~d})$ were at greater risk of retained placentas after calving possibly due to the placenta failing to mature.

Negative effects on performance and health have been associated with feeding a close-up ration for longer than the recommended 3-wk period (Mashek and Beede, 2001); to our knowledge, this is the first study to show that fewer days on the close-up TMR increased risk of metritis. The NRC (2001) recommends feeding a diet containing approximately 1.25 $\mathrm{Mcal} / \mathrm{kg}$ of $\mathrm{NE}_{\mathrm{L}}$ (far-off diet) until $21 \mathrm{~d}$ before calving and then 1.54 to $1.62 \mathrm{Mcal} / \mathrm{kg}$ of $\mathrm{NE}_{\mathrm{L}}$ (close-up diet) for the last $3 \mathrm{wk}$ preceding parturition. The close-up ration is specifically formulated to provide the necessary protein, energy, and mineral levels required to make the metabolic and physiological adaptations necessary for parturition and the onset of lactation (NRC, 2001). The cows that went on to develop severe metritis in the present study were already consuming less DM than cows that remained healthy, and may have been further compromised nutritionally by spending fewer days on the diet. These results would support the rec- 
ommendation to ensure adequate prepartum nutrition to maintain health after calving.

In the present study, prepartum BW and BCS, as well as parity, were not useful as predictive measures for severe metritis. Numerous studies have attempted to relate these factors to health after calving but results have been inconsistent. For example, Gröhn et al. (1990) reported no association between metritis and parity, whereas Markusfeld (1984) reported that firsttime calvers were at the greatest risk for metritis. Bruun et al. (2002) suggested that both first-parity cows and cows of third parity or higher were at the greatest risk for this disease. In each of these studies cows were maintained under varying management conditions, which may explain the lack of consistency in how parity relates to health status after calving. For example, group size and composition and frequency of mixing new herdmates may influence heifers and cows, and consequently their susceptibility to disease, differently. Contreras et al. (2004) examined BCS during transition and subsequent effects on health, and reported increased rates of $\mathrm{RP}$, ketosis, and milk fever in cows that had a BCS $\geq 3.25$ compared with a BCS $\leq 3.0$ at dry off. Kaneene and Miller (1995) reported that over- and underconditioned cows were at greater risk for metritis. Interestingly, DMI has been shown to decrease linearly with increasing BCS during the prepartum period (Hayirli et al., 2002), which may partially explain the relationship between postpartum health and prepartum BCS. However, in the present study we found no relationship between prepartum BCS and prepartum intake. This may be attributed, in part, to a limited sample size, and may also be a consequence of low variation in BCS of the cows used in the current study.

To our knowledge this is the first study to examine the relationship between water intake and postpartum health status in transition dairy cows. When investigated as a single factor, reduced water intake during the week before calving tended to be a risk factor for severe metritis; however, the odds ratio for this factor was much lower then the odds ratios for DMI and feeding time. Over the course of the study differences in water intake between mildly metritic and healthy cows were more significant than differences in water intake between severely metritic and healthy cows. A larger sample size of severely metritic animals is likely needed to detect significant differences in prepartum water intake between health categories, because differences in water intake before calving among the 3 health categories were more subtle than the differences observed for prepartum DMI and feeding time.

During the week before calving, water intake differed little between severely metritic and healthy ani- mals, despite the fact that DMI is generally correlated with free water intake (Murphy, 1992). When looking at the diurnal pattern of water intake during the week before calving, we observed that cows that went on to develop severe metritis consumed less water during peak feeding times (the period following fresh feed delivery). These cows, however, appeared to compensate for at least a portion of this lower water intake by consuming more than healthy cows at other hours of the day. An explanation for why these animals may be able to maintain higher levels of water intake during the prepartum period may be that the time needed to consume water is considerably less than the time needed to consume food. Consequently, aggressive interactions at the water trough may have less effect on water intake than they do on feed intake.

Although this study showed positive relationships between drinking time and water intake during both pre- and postpartum periods, only $26 \%$ of the variation in water intake could be explained by drinking time, suggesting that cows varied greatly in the time spent at the water trough. One limitation of the Insentec system for monitoring drinking and feeding time is that the system records the time that a cow spends at the feed or water bin, not the amount of time that the cow is actually consuming water or feed. Because cows require only minutes to consume their water requirements (Huzzey et al., 2005), it is possible that this variation in drinking time is actually due to variation in the time cows spend at the water trough but not drinking.

It is generally accepted that DMI declines over the week before calving, contributing to the negative energy balance after parturition (Grummer et al., 1995, 2004; Dann et al., 1999). However, these reports often fail to consider postpartum health status. The aim of most transition cow management programs is to improve DMI prepartum, thereby minimizing the negative energy balance after calving. The results of the current study show that only some cows exhibit a dramatic decline in DMI in the week before calving. Cows that remained healthy throughout the entire transition period showed little decline in DMI in the period before calving. In contrast, cows with severe metritis showed a notable decline in daily DMI beginning $1 \mathrm{wk}$ before calving.

Of the potential prepartum risk factors for metritis that were evaluated in this study, wk -1 feeding time and DMI were best able to identify cows at risk for severe metritis after calving. These results complement other studies that have examined the relationship between feeding behavior and health. An earlier study by our research group showed that the odds of a positive diagnosis of acute metritis increased by 1.57 
for every 10-min decrease in feeding time during the 2 wk before calving (Urton et al., 2005). This value compares well with the results of the current study, which showed a 1.72 increase in risk for every 10min decrease in feeding time during the week before calving. Work completed by Quimby et al. (2001) with feedlot steers indicated that reduced feeding behavior could be used to detect animal morbidity approximately $4.1 \mathrm{~d}$ earlier than identification by pen riders. Hammon et al. (2006) reported lower DMI, relative to healthy animals, during the 2 -wk period before calving for cows that went on to develop puerperal metritis.

The results of the current study and those of previous studies provide clear evidence that reduced feeding time and DMI during the period before calving increases the risk of cows developing infectious disease after calving. However, whether a reduction in intake and feeding time before calving is a cause of infectious disease after calving or an effect of something else going on during the prepartum period is not known. Ketotic environments (i.e., low concentrations of plasma glucose and high concentrations of NEFA and BHBA) have been shown to impair immune function through a variety of pathways (Sato et al., 1995; Suriyasathaporn et al., 1999; Zdzisinska et al., 2000). Hammon et al. (2006) reported that cows that went on to develop puerperal metritis had a greater degree of immunosuppression relative to healthy animals as measured by neutrophil function. Compromised immune status as a result of inadequate nutrition during the prepartum period may increase a cow's susceptibility to metritis; however, the underlying reason for the reduction in feeding behavior in some cows and not others is not known.

Our investigations into the behavior of dairy cows during the prepartum period provide the first evidence that social behavior may play an important role in disease susceptibility in dairy cattle. During the week before calving cows later diagnosed with severe metritis engaged in fewer aggressive interactions at the feed bunk (i.e., displaced others from the feed bunk less often) and had reduced feeding and drinking times especially during the periods following fresh feed delivery. Previous work has shown that the motivation to feed is greatest immediately following the delivery of fresh feed, and that competition at the feed bunk is greatest at this time (DeVries and von Keyserlingk, 2005). Cows that were diagnosed with severe metritis after calving appeared to be less motivated to compete for access to the feed before to calving. A low propensity to compete for access to feed may indicate that these cows are socially subordinate and unwilling to engage in interactions with more dominant individuals.
The reduction in prepartum feeding activity experienced by some individuals may also be a consequence of differences in coping strategies between individuals. There are numerous changes that occur during the transition period including regrouping of animals. The group structure within the prepartum pen in this study was dynamic with cows entering and leaving the group on average every $3 \mathrm{~d}$. Unfortunately, this dynamic group structure makes classification of animals in terms of social hierarchy difficult, because this is dependent on an individual's relationship to others housed in the same pen (Langbein and Puppe, 2004). Socially subordinate animals may not be able to cope with frequent restructuring of the social hierarchy resulting in reduced feeding time and DMI and increased avoidance behavior in response to social confrontations, putting these cows at greater risk of nutritional deficiencies that impair immune function and increase susceptibility to disease. In the present study, groups consisted of both primiparous and multiparous cows, and these animals shared access to the same feeders. Both of these factors could influence social dynamics within the group with the socially subordinate cows being most affected (Phillips and Rind, 2001; Huzzey et al., 2006). New work is now required to better understand transition cow responses to management practices such as regrouping, and how this affects their susceptibility to disease after calving.

\section{CONCLUSIONS}

The results of this study indicate that both prepartum DMI and feeding behavior, particularly during the week before calving, can identify cows at risk for metritis after calving. We also provide the first evidence that cows that go on to develop metritis engage in fewer aggressive interactions at the feed bunk during the week before calving, and avoid the feed bunk during periods when competition for feed is highest. These results suggest that environmental and social factors may be important in determining the level of feeding activity in individual cows during the prepartum period and subsequently may influence postpartum health status.

\section{ACKNOWLEDGMENTS}

We would like to thank the staff of The University of British Columbia Dairy Education and Research Centre and the University's Animal Welfare Program. In particular we thank Katy Proudfoot for her contributions to daily data collection, Renu Singh for her help in analyzing the video recordings of social behavior, and Trevor DeVries for his comments on the statis- 
tical analyses. This project was funded by the Natural Sciences and Engineering Research Council of Canada and Dairy Farmers of Canada and many other donors listed on the Animal Welfare web site at http:// www.landfood.ubc.ca/animalwelfare.

\section{REFERENCES}

Bell, A. W. 1995. Regualtion of organic nutrient metabolism during transition from late pregnancy to early lactation. J. Anim. Sci. 73:2804-2819.

Bruun, J., A. K. Ersbøll, and L. Alban. 2002. Risk factors for metritis in Danish dairy cows. Prev. Vet. Med. 54:179-190.

Burgos, M. S., M. Senn, F. Sutter, M. Kreuzer, and W. Langhans. 2001. Effect of water restriction on feeding and metabolism in dairy cows. Am. J. Physiol. Regul. Integr. Comp. Physiol. 280:R418-R427.

Canadian Council on Animal Care. 1993. Guide to the Care and Use of Experimental Animals. Vol. 1. E. D. Olfert, B. M. Cross, and A. A. McWilliam, ed. CCAC, Ottawa, Ontario, Canada.

Contreras, L. L., C. M. Ryan, and T. R. Overton. 2004. Effects of dry cow grouping strategy and prepartum body condition score on performance and health of transition dairy cows. J. Dairy Sci. 87:517-523.

Curtis, C. R., H. N. Erb, C. J. Sniffen, R. D. Smith, and D. S. Kronfeld. 1985. Path analysis of dry period nutrition, postpartum metabolic and reproductive disorders, and mastitis in Holstein cows. J. Dairy Sci. 68:2347-2360.

Dann, H. M., G. A. Varga, and D. E. Putnam. 1999. Improving energy supply to late gestation and early postpartum dairy cows. J. Dairy Sci. 82:1765-1778.

Deluyker, A., J. M. Gay, L. D. Weaver, and A. S. Azari. 1991. Change of milk yield with clinical diseases for a high producing dairy herd. J. Dairy Sci. 74:436-445.

Detilleux, J. C., M. E. Kehrli, Jr., J. R. Stabel, A. E. Freeman, and D. H. Kelley. 1995. Study of immunological dysfunction in periparturient Holstein cattle selected for high and average milk production. Vet. Immunol. Immunopathol. 44:251-267.

DeVries, T. J., and M. A. G. von Keyserlingk. 2005. Time of feed delivery affects the feeding and lying patterns of dairy cows. J. Dairy Sci. 88:625-631.

DeVries, T. J., M. A. G. von Keyserlingk, and D. M. Weary. 2004. Effect of feeding space on the inter-cow distance, aggression, and feeding behavior of free-stall housed lactating dairy cows. J. Dairy Sci. 87:1432-1438.

Gröhn, Y. T., H. N. Erb, C. E. McCulloch, and H. S. Saloniemi. 1990. Epidemiology of reproductive disorders in dairy cattle: Associations among host characteristics, disease and production. Prev. Vet. Med. 8:25-39.

Gröhn, Y. T., P. J. Rajala-Schultz, H. G. Allore, M. A. DeLorenzo, J. A. Hertl, and D. T. Galligan. 2003. Optimizing replacement of dairy cows: modeling the effects of diseases. Prev. Vet. Med. 61:27-43.

Grummer, R. R., P. C. Hoffman, M. L. Luck, and S. J. Bertics. 1995 Effect of prepartum and postpartum dietary energy on growth and lactation of primiparous cows. J. Dairy Sci. 78:172-180.

Grummer, R. R., D. G. Mashek, and A. Hayirli. 2004. Dry matter intake and energy balance in the transition period. Vet. Clin. North Am. Food Anim. Pract. 20:447-470.

Hammon, D. S., I. M. Evjen, T. R. Dhiman, J. P. Goff, and J. L. Walters. 2006. Neutrophil function and energy status in Holstein cows with uterine health disorders. Vet. Immunol. Immunopathol. 113:21-29.

Hayirli, A., R. R. Grummer, E. V. Nordheim, and P. M. Crump. 2002. Animal and dietary factors affecting feed intake during the prefresh transition period in Holsteins. J. Dairy Sci. 85:3430-3443.

Huzzey, J. M., T. J. DeVries, P. Valois, and M. A. G. von Keyserlingk. 2006. Stocking density and feed barrier design affect the feeding and social behavior of dairy cattle. J. Dairy Sci. 89:126-133.
Huzzey, J. M., M. A. G. von Keyserlingk, and D. M. Weary. 2005. Changes in feeding, drinking, and standing behavior of dairy cows during the transition period. J. Dairy Sci. 88:2454-2461.

Kaneene, J. B., and R. Miller. 1995. Risk actors for metritis in Michigan dairy cattle using herd- and cow-based modeling approaches. Prev. Vet. Med. 23:183-200.

Kimura, K., J. P. Goff, M. E. Kehrli Jr., and T. A. Reinhardt. 2002 Decreased PMN function as a cause of retained placenta in dairy cattle. J. Dairy Sci. 85:544-550.

Langbein, J., and B. Puppe. 2004. Analysing dominance relationships by sociometric methods-A plea for a more standardized and precise approach in farm animals. Appl. Anim. Behav. Sci. 87:293-315.

Mallard, B. A., J. C. Dekkers, M. J. Ireland, K. E. Leslie, S. Sharif, C. Lacey Vankampen, L. Wagter, and B. N. Wilkie. 1998. Alteration in immune responsiveness during the periparturient period and its ramification on dairy cow and calf health. J. Dairy Sci. 81:585-595.

Markusfeld, O. 1984. Factors responsible for post-parturient metritis in dairy cattle. Vet. Rec. 114:539-542.

Markusfeld, O., N. Galon, and E. Ezra. 1997. Body condition score, health, yield and fertility in dairy cows. Vet. Rec. 141:67-72.

Mashek, D. G., and D. K. Beede. 2001. Peripartum responses of dairy cows fed energy-dense diets for 3 or 6 weeks prepartum. J. Dairy Sci. 84:115-125.

Melendez, P., J. McHale, J. Bartolome, L. F. Archbald, and G. A. Donovan. 2004. Uterine involution and fertility of Holstein cows subsequent to early postpartum $\mathrm{PGF}_{2 \alpha}$ treatment for acute puerperal metritis. J. Dairy Sci. 87:3238-3246.

Murphy, M. R. 1992. Symposium: Nutritional factors affecting animal water and waste quality. Water metabolism of dairy cows. J. Dairy Sci. 75:326-333.

National Research Council. 2001. Nutrient Requirements of Dairy Cattle. 7th rev. ed. National Academy Press, Washington, DC.

Olofsson, J. 1999. Competition for total mixed diets fed for ad libitum intake using one or four cows per feeding station. J. Dairy Sci. 82:69-79.

Opsomer, G., Y. T. Gröhn, J. Hertl, M. Coryn, H. Deluyker, and A. de Kruif. 2000. Risk factors for post partum ovarian dysfunction in high producing dairy cows in Belgium: A field study. Theriogenology 53:841-857.

Paisley, L. G., W. D. Mikelsen, and P. B. Anderson. 1986. Mechanisms and therapy for retained fetal membranes and uterine infections of cows: A review. Theriogenology 25:353-381.

Phillips, C. J. C., and M. I. Rind. 2001. The effects on production and behavior of mixing uniparous and multiparous cows. J. Dairy Sci. 84:2424-2429.

Quimby, W. F., B. F. Sowell, J. G. P. Bowman, M. E. Branine, M. E. Hubbert, and H. W. Sherwood. 2001. Application of feeding behavior to predict morbidity of newly received calves in a commercial feedlot. Can. J. Anim. Sci. 81:315-320.

Rajala, P. J., and Y. T. Gröhn. 1998. Effects of dystocia, retained placenta, and metritis on milk yield in dairy cows. J. Dairy Sci. 81:3172-3181.

SAS Institute. 2003. SAS User's Guide. Version 9.1. SAS Institute Inc., Cary, NC.

Sato, S., T. Suzuki, and K. Okada. 1995. Suppression of mitogenic response of bovine peripheral blood lymphocytes by ketone bodies. J. Vet. Med. Sci. 57:183-185.

Sheldon, I. M. 2002. Effect of postpartum manual examination of the vagina on the uterine bacterial contamination in cows. Vet. Rec. 151:531-534.

Sheldon, I. M., G. S. Lewis, S. LeBlanc, and R. O. Gilbert. 2006. Defining postpartum uterine disease in cattle. Theriogenology 65:1516-1530.

Sowell, B. F., J. G. P. Bowman, M. E. Branine, and M. E. Hubbert. 1998. Radio frequency technology to measure feeding behavior and health of feedlot steers. Appl. Anim. Behav. Sci. 59:277-284.

Sowell, B. F., M. E. Branine, J. G. P. Bowman, M. E. Hubbert, H. W. Sherwood, and W. F. Quimby. 1999. Feeding and watering behavior of healthy and morbid steers in a commercial feedlot. J. Anim. Sci. 77:1105-1112. 
Suriyasathaporn, W., A. J. Daemen, E. N. Noordhuizen-Stassen, S. J. Dieleman, M. Nielen, and Y. H. Schukken. 1999. Betahydroxybutyrate levels in peripheral blood and ketone bodies supplemented in culture media affect the in vitro chemotaxis of bovine leukocytes. Vet. Immunol. Immunopathol. 68:177-186.

Urton, G., M. A. G. von Keyserlingk, and D. M. Weary. 2005. Feeding behavior identifies dairy cows at risk for metritis. J. Dairy Sci. 88:2843-2849.
Wildman, E. E., G. M. Jones, P. E. Wagner, R. L. Boman, H. F. Troutt, and T. N. Lesch. 1982. A dairy cow body condition scoring system and its relationship to selected production characteristics. J. Dairy Sci. 65:495-501.

Zdzisinska, B., J. Filar, R. Paduch, J. Kaczor, I. Lokaj, and M. Kandefer-Szerszen. 2000. The influence of ketone bodies and glucose on interferon, tumor necrosis factor production and NO release in bovine aorta endothelial cells. Vet. Immunol. Immunopathol. 74:237-247. 